\title{
WILLIAM SALTER'S "MY MINISTRY IN IOWA, 1843-1846"
}

\author{
Edted by Philip D. Johdan
}

\section{[Concluded]}

Br. E. Alden has spent a few days with me, informs me that [the] brethren met in April at Denmark [and] concluded that it was important to make a beginning in relation to a College and appointed Rev. Asa Turner ( $p .4$ ) their agent to collect funds in the East for the purchase of a college site and to raise a colony. Rev. Mr. Boal was ordained in April at Black Hawk by Des Moines Presbytery. Mr. C. R. Fisk after having [78] succeeded in the erection of a meeting house at Black Hawk [and] has lost the favor of the people and is about leaving. He is a son of Rev. Mr. Fisk of Wrentham, Mass. Br. Alden is very much encouraged at Tipton. Has formed a church of three members-is contented.

Mr. Payburn and family have all been to meeting regularly since death (p. 68) of their little boy. Before that he had not been to meeting since I came here, and had not been in the memory of his oldest neighbors here. He confesses his sin.

May 28. Visited last week Maquoketa cave (p. 48) in Company with Bs. Holbrook and Alden-in the site of the natural bridge felt the inadequacy of all descriptions I had given of it. 'Thru fear of exaggeration I had not told the half. In our company were Mr. Holbrook, Mr. Van Horn and his sisters, Mr. Dennison and his sister, Mrs. Monatague. The passing thru the cave immediately below the bridge was an occasion of exciting interest. We had with us a few dim candles, none of us had ever heard any particular description of the cave. It was literally terra incognito-a branch of the Creek runs thru the cave which keeps it wet and muddy. On we went more and more venturesome, thru wet mud. Having [79] gone about 500 feet we came to a bend of the cave to the right where the water obstructed the farther progress of the ladies. Br. Alden, Mr. Van Horn and myself waded through the water and soon reached the mouth of this cave at the other end. The cave must be some 600 or 800 feet long. Farther down the ravine we entered the mouths of other eaves but having unfortunately put our lights out were unable to make farther explorations.

On returning in crossing South Fork at Phillipps Ford my horse which was in Mr. Holbrook's wagon lay down in the water, broke one of the shafts. Mr. H[olbrook] and myself got into the water, pried the horse from the buggy and dragged it to shore. Fortunately, Mrs. $\mathrm{H}$ [olbrook] had exchanged her seat in the buggy for the horse I was riding. 
Last week attended Iowa North Association at DeWitt. ['There] were present Brs. Holbrook, Alden, Emerson and self, and delegates from churches in Andrew, DeWitt and Maquoketa. A day of small things. But oh, how rapid and great the increase of the next twenty or even ten years. 'The subject of a union of Congregational and Presbyterian Churches in Northern Iowa was discussed-Brs. Holbrook and Turner appointed to correspond on the subject and report a plan of Union.

[80] June 17. Have got behind in writing up my Journal from want of time. Spent the first Sabbath of this month in Mineral Point. 'This settlement the next oldest to that of Galena in the mines. There was a stockade there during the Black Hawk war. The ministers who have preached there are Messrs. Chaffin,[?] Adams, and Cooke. 'The last a brother of Parson Cooke of Lynn, Mas., was in Michigan city. His removal to Mineral Point was contrary to the views of Mr. Badger, is regarded as an able preacher but harsh on those whose opinions differ from his. His manner not prepossessing (p. 71). Mr. Gallahin[?] labored there when in this region-is to be expected some of his converts are gone back and others (Mr. Brackin, Mr. Tilly) are decided useful Christians. Mr. Curtis Beath is the main pillar of this church, from $N[$ ew] York State, a successful merchant, regarding himself as a stewart of the Lord. Mr. Hatch, one of his clerks, is a promising young mall, Mr. Carter [is] the chorister, his wife a member of the church, Mr. Rhinderson, his wife is a daughter of Mr. Mosley.

June 3. [1] attended a three days meeting at Elk Grove in $\mathrm{Mr}$. Henry Curtis' barn. One of the most solemn and blessed meetings I ever attended, Mr. Henry Curtis and wife, Horace Curtis and their father, a man of gray hair, Capt. Deklerstl?] and wife and nephew of [81] same man and wife and others came forward and named themselves on the Lord's side.

On Friday June $7 \mathrm{Br}$. J. J. Hill arrived in Dubuque. L.ast week 1 went up to see him, was much pleased with the energy, activity and soul of his wife. I hired a buggy and drove him to Clayton Co. [Went] west to Floyd's by Burtis' furnace, 20 miles N. W. of Dubuque whence 12 miles to Millville on Turkey river at the mouth of a creek, the Little Iurkey. Miller Church is about four miles from the North 'lurkey river. We found the river very high and not fordable, and swam my horse, took our wagon apart and carried it over on a skiff-found Mr. Emerson, one of the mill owners, a very smart and polite man, became acquainted with Major Lands[?] a large land holder in that region. Spent the night with Mr. Grevill, Pennsylvania Dutch. The road very bad and full of stones between Floyd and Millville. Jacksonville, the County Seat of Clayton, is handsomely situated on a high rolling prairie, good timber at the distance of a mile on two sides of it. Stopped with Mr. James Watson, native of $\mathrm{N}$ [orth] Carolina, lived in Missouri, lived in Dubuque, was elder in Presbyterian churches there, an upright man, has a large flock of sheep, in partnership with $\mathrm{Mr}$. 
Thompson of Dubuque. His wife a fine woman of gentle manners, in feeble health. [82] Spent the night with Mr. Jay, an excellent and faithful brother, formerly a member of church in Princeton, IIl. and now of Potosi, W. 'T. Mr. Kirkpatrick, member of [the] church in Potosi lives with him. Called on Mr. Kinney. Mr. Banfield keeps public house.

13th inst. Rode to l3oardman's [a distance of 13 miles. He was native of Vermont, educated under Presbyterian principles, engaged in [the] milling business in North Eastern $\mathrm{N}[\mathrm{ew}$ ] York and in Canada, came some eight years ago by way of Green Bay to this place, went up Turkey river in a boat in search of mill privilege and selected his present site, the river runs over a rock bottom with rock sides, some ten feet high and a little beyond this are higher banks, whence a level plain extending back to bluffis 100 feet high.. A dam can easily be built and thus [is] an extellent site for building mills. 'There is a natural way for constructing a channel for which to carry water down along the banks. There are ten or twelve families in the neighborhood, but Mr. Boardman thinks there are several sections of good farming land still unoccupied. Mr. Broser[?] and family live with Mr. Boardman. I told Mr. Boardman in relation to the enterprise now on foot to establish an academical institution in Iowa and that its friends were looking around for a favorable location. He expressed [83] considerable gratification that his place should be visited with reference to this and a willingness to dispose of part of his interests there to such an ob.ject.

On June 3, this region was visited with an extensive and destructive hurricane. At [the] mouth of Lytle's creek the house of Jesse Ladi was thrown down and his family much injured. Stout oak trees were thrown to the ground, injury was done in Clinton, Cedar and Iowa County. Home of Mr. Snow [?] at DeWitt was thrown down. At Albany, Moline, and other places in Illinois injury was done.

On returning from Boardman's last week, crossed the Turkey a mile below Boardman's, crossed the Volga and Elk creek[s] near Wignam settlement by a saw mill and rode to the Colony Settlement in the edge of Clayton and Deleware thru much timber till $91 / 2$ P. M. in [the] dark evening when [I] came to the home of Mr. Mallory, when seamed up [sic] the people and lodged-a large family [of] eight or nine sons, a pine log house. Mr. M[allory] brought up a Presbyterian but now a Nothingarian from $\mathrm{N}[\mathrm{ew}]$. York. Ancestors from Conn't. Mr. Morlin, a brother, family to stay with a mile this side. Mr. Montgomery in that settlement is an $\mathrm{O}[\mathrm{ld}] \mathrm{S}$ [chool] Presbyterian. Mr. Cole, Universalist preacher, important in his timber [?], has settled in that neighborhood, proud and conceited man-of considerable reading. Friday, June 14, rode [84, all day in most severe rain, by Floyd's 24 miles and reached Dubuque just before dark. One mile West of Floyd's passed in the road one cross some twenty-five feet high and smaller ones some ten feet high in front of a Romish mass house. Thus in all this journey 
of some 175 miles I passed but one meeting house and saw but one preacher (with the exception of those in Dubuque) and that meeting house was a Romish one and that preacher a Universalist.

July 22. Am again far behind in my Journal, have not had opportunity to make a record.

The church at Mineral Point have given Mr. Warren a call. They blundered in sending for me while he had their application to him still under consideration. He was an old personal friend of Mr. Beach and the man of his choice.

At Platteville, on the 26th June received a call from [the] church in Potosi to settle with them-visited there and found a good degree of cordiality and unanimity towards me among the people. I thought I should leave the matter to the decision of the A. H. M. S., but in [a] letter received today from the Society nothing is said on the subject, though in my report to them on May 9th I asked their advice. Saw Mr. Peet in Dubuque last week. He advised strongly my going to Potosi and [85] guaranteed me of the sanction of the A. H. M. S. in so doing. I wait only for more light.

Mr. Brown, school teacher in Mineral Point is a worthy young mannot polished but naturally of good strong inquiring mind. Mr. Hallow, Primitive [sic] Methodist preacher, an amiable man.

In Platteville heard Mr. Ravenaugh, presiding Elder, lecture on Tempcrance-an easy fluent speaker, rather pompous and hearty-native of Kentucky.

Mr. White who owns the house Br. Stevens lives in and boards with him, was an Indian trader in Milwaukee.

In Potosi, Mr. Lyon [is] a very pious man, praying much, belongs to Primitive Methodist, also Mr. Greenwood.

Of the members of [the] Presbyterian church are, Mr. Cussins, (two brothers) Mr. Bristow, native of Kentucky, converted under Mr. Peet's and Mr. Holbrook's laborers there, Mr. Neaville, native of Ohio, where was brought up with Calvinistic Baptists.

Spent 4th July at Dubuque-rained severely. Heard address of Messrs. Green and Merrit and of Br. Holbrook. Oh, it was delightful to hear the memories of our Puritan ancestors spoken of with veneration and love this side of the Mississippi. [86] The Sabbath School celebration was very interesting. I enjoyed it much-Mr. Holbrook urged on the children the importance of studying the Bible which offended some Papists who were present.

The country was very wet the last of June and the first part of th: month. The Maquoketa very high, crops destroyed. The two last Sabbaths have been very pleasant. My congregaion has generally been about fifty in from different places.

Was glad to meet in Dubuque Rev. C. H. A. Bulkly (p. 67). He intends locating in Wisconsin. Mr. Peet is pleased with him and his qualifications for usefulness.

July 23. Enjoyed a swect and profitable season of prayer $1 / 2$ mile 
West of Deacon Cotton's yesterday-committed my way unreservedly to the Lord.

August 17. Rode to Tete Des Morts [on] July 25, so called from the legend that a band of Indians was driven off by their foes to a precipitious bluff near the mouth of the creek whence they cast themselves on the rocks beneath, preferring destruction in this way to falling into the hands of their enemies. Spent the night with Mr. Potter's [87] family. Mrs. P[otter] seems to have been converted. Mr. P[otter] unwilling and $I$ know not but unable to lift the voice of prayer in his family, two interesting boys, NeIson and Philip.

Crossed the Mississippi at [the] mouth of 'Tete Des Morts in a skiff in the rain, and walked to Galena thru the mud. Enjoyed the hospitalities of Mr. Kent. Rode to Potosi in stage, fare \$1.50. Dined at Menominie (Mr. Gilman's, an old settler) this is one of Br. Lewis's preaching places, crossed the Platte river at Junction of Big and Little Platte. On the other side is Paris where are some ten good dwelling houses, but onc family-at one time a little business was done there, now none.

July 28. [I] had a large congregation at Potosi, the house full. Visited there this week Mr. Gingsly, lived in Missouri (under the influence and a great admirer of Dr. Nelson, has a second wife, has united with the Methodists-belongs to Presbyterian church). Neaville, Bristow, MeSchend[?] Ayres. (here saw Mr. Sawyer and sister, natives of New Ipswich, N. H. now residing in Denmark, I. T. and Mr. Case from Ohio [who] has lived some two years in Denmark, I. T.)

July 29. Rev. E. Adams came to see me. I rode with him to Cassvillc, stopping over night with Mrs. Booth, from Lister Mass., Methodist family, Br. Adams is laboring in one [88] of our most thickly populated counties, the people are western, and the ground occupied by $O$ [Id] S[chool], Cumberland Presbyterians, [Liciden?] so that if a more open door for usefulness should be set before him, it would be his duty to leave.

At Cassville I saw Mr. Street (page $r 1$ ). He had preached his farewell sermon to the church and expects to remove his family in Sept. to the neighborhood of his relatives at the Old Agency in Wapello Co., Iowa. Dined with Mr. Richards, his wife a daughter of Mr. Curtis (p. 80) has been unfortunate in his affairs. Cassville has a very pleasant location, good landing, will be a fine town when the back country is settled. Spent a night with Mrs. McCartwright[?] (sister of Mrs. Kilbourne), a good woman, married last spring to Mr. Mc[Cartwright] who was a widower with large family and sceptical.

Dined with Mr. Fred Sprague on Grant river, a very intelligent Christian from Ontario County, N. Y., lived many years in Michigan.

Monday morning, August 5, by daylight started for Beloit, in company with Miss Fisher ( $p$ 74). Mr. Rice took us to Platteville 16 miles, whence in a wagon with Br. Stevens and Holbrook to New Diggings, 16 miles, where fell in with Bros. Turner, and Adams, to $\mathrm{Mr}$. 
Clymire's[?] 14. miles on the Eastern [89] edge of Guetoit's[?] grove where I spent the night. The next morning over the prairie to Windslow 19 miles, breakfasted with Mr. Knuland, brother of Mrs. Meacham near Cascade. Windslow is on the Pickatomic. 'The property chicfy owned in Boston. Mr. Gardner, Hardware Merchant, a large owner, a good mill-drove that afternoon thru Oneco where is Rev. $\mathrm{Mr}$. Hazard to Logan Creek grove, put up at Mr. Pirson's[?] 26 miles, saw Mr. Moffet who has recently purchased the farm [and] intends to have 300 Acres in wheat this fall. [He is] from N[ew] Jersey and Orange Co., N|cw $]$ York, lived in Milwaukee, belonged to Mr. Miter's church and paid 200 dollars for the meeting house there. The next morning drove to Bcloit eighteen miles, thus 109 miles from Potosi to Beloit. At Beloit enjoyed the hospitality of Mr. Bickerall, who keeps the Beloit House and of Miss Fisher's family.

Beloit is a beatiful village well laid out, spacious streets, on the East bank of Rock river-the buildings are new. The Congregational church is a very fine stone building, plain and handsome and commodious.

The Subject of a College in Wisconsin and Northern Illinois had been talked of for several years and premature steps have frequently been taken but nothing decisive and satisfactory [90] accomp'ished. In Convention in Cleveland in June were several interested in this object and Rev. ' $I$. Baldwin and a convention of friends to the cause in Northcrn Illinois, Wisconsin and Iowa was proposed to be held in Beloit Aug. 6 to consult in establishing Colleges and more particularly on their location. In pursuance of an informal call in this way, some sixty gentlemen were met in Beloit. The Rev. A. Kent was appointed Chairman and Mr. Jason March of Rockford Seminary. Convention opened with prayer by Rev. S. Peet.

It was unanimously agreed that Iowa should have a College by itself, but much discussion was had and much sectional prejudices manifested as to [a] union of Wisconsin and Northern Illinois in establishing one College. Each seemed to be very willing to unite with the other, if the other would unite in building the college on their side of the line. It was however, finely agreed so that it was expedient for Northern Illinois and $W$ isconsin to unite in establishing one College. It was proposed to establish the institution on the line, but finally agreement was come to a proposition of Mr. Kent['s] to establish [91] both a College and a female Seminary-Beloit and Rockford are the rival places for these institutions. A Committee of ten was appointed to examine and report on [the] subject of [the] location of them to the next Convention, which is to consist of each minister and delegate from each church in Northern Illinois and Wisconsin, to be held Oct. 29 at Beloit.

I became slightly acquainted with most of the gentlemen present. Mr. Clary[?] pastor of the church in Beloit seems to be a thorough, active and efficient man, a clear mind, his wife a sister of Rev. $J$. Burchard[?] Mr. Clark was formerly in Watertown, N[ew] York. 
Rev. H. Foote of Racine, A. Gaston (Delevan) of amiable appearance, H. Laurence of Elkhorn, in Lane Seminary with [the] class of Rev. O. Emerson, lately in Toledo, Ohio, which he left in consequence of its sickliness. Marcus Hicks of Chicago an active stirring man. N. Wright of Belvidere [is] of solid character and substantial worth. Hiram March, Instructor in Galesburg, of practical common sense. C. Waterbury of Freeport, opinionated and dogmatic. Ebinezer Brown of 12 mile grove, of good judgment and warm and generous heart. O. W. Nuton, of Roscoe, of N[ew] York Theo[logical] Seminary. Lewis Benedict of Picatonic, H. Taylor [92] has bought a farm near Picatonic, and C. Clark Elgin[?] R. M. Pearson, page 3, Grand De Tour J. B. Potter, Rockford, S. Smalley Amazorl?] T. Baldwin, Alton, J. J. Minton[?], Milwaukee, A. I.. Chapin, Milwaukee, O. B. Clinton, Azatalar, S. E. Mims, Madison, E. W. Hewitt, Milton, C. Nichols, Lafayette, C. E. Rosenkrans, Troy, C. H. A. Bulkley, Janesville, L. Bridgeman, Beauwaukee[?]. E. B. Turner, Jno. C. Holbrook, E. Adams [from] Iowa. I. H. Loss, Ohio, Besides lay gentlemen from various places. Mr. Loss made some valuable remarks on the subject of common school and academical education. Mr. L[oss] has become principal of an Academy at Beloit. Returning we came to Cummings in Rock grove 29 miles, to Windslow 15 miles, to New Diggings by way of Gratiot's mill on Wolf creck, thirty-four miles and to Bellevue by way of Galena 26 miles. Visited Bellevue and Charleston and the Forks this week and returned to Cottonville yesterday.

Aug. 20. Cottonville. A very heavy rain last Saturday night and Sabbath morning. Rode in the rain to county seat, but four persons present. Had a prayer meeting-went on to Maquoketa and had a small congregation.

Rec'd. yesterday a letter (Aug. 30) from Mr. Badger advising [93] me to remain in Iowa. ${ }^{89}$ I trust it is of the Lord, and tho in many respects the field in Potosi would have been a more desirable one to labor in, I cheerfully shall endeavor to brave the hurt and burden of the day here.

Cottonville, Sept. 12, 1844. Went to Dubuque, Mr. Kilbourne's (where took tea, Mrs. K[ilbourne] confined,) and Fairplay where enjoyed hospitality of Mr. Rood (p. 38) August 23. Next day [went] to Platteville where made known to $\mathrm{Br}$. Stevens the contents of my letter from Mr. Badger. Br. S[tevens] was much affected in view of the suffering conditions of [the] church in Potiso, thought the advice of the A. H. M. S. injudicious, and was rather of [the] opinion that I ought to go notwithstanding. Went to Potosi that afternoon and spent the Sabbath [and] had a large congregation in the forenoon, some 150. The Church expressed much regret in view of my declining a call and unanimously and feelingly renewed their expressions of attachment to me, and of [the] desire that I might become Pastor of the Church.

${ }^{89}$ This letter is quoted in Ellis, op. cit., p. 671. 
Monday Aug. 26. Rode to Cassville, enjoyed hospitality of Mr. Fred Sprague and of Mr. Richards (p. 88) crossed the river 'luesday morning, was landed in the mud, and traveling through stones, mud, and "sinking dry places" over the bottom below [the] mouth of liurkey river which has been overflowed most of the season. Crossed the 'lurkey in the dirty bottom of a frail canoe, swimming my horse and reaclied Jacksonville ${ }^{00}$ (p. 81) that afternoon. Br. Hill91 has made a good starl, secured the affections and confidences of the community, and hais encouraging prospects for all which due credit must be given to his amiable, cheerful, happy and happy-making wife. A Congregalional church was formed Sept. 1. Watson and Gay were elected dencons. The Articles of Faith and Covenant are generally those of the $W$ isconsin Convention. The members are: Br. Hill and wife, Watson and wife, ${ }^{92}$ Gay and wife ${ }^{93}$ and two daughters, ${ }^{94}$ Kinney and wife $e^{3 \pi}$ and Kirkpatrick. ${ }^{06}$

Rev. A. M. Wells, Chaplain at Fort Crawford, Prairie Du Clien, (18 miles $\mathrm{N}$ [orth] East) was present and preached one sermon from Ezek. $18: 31.07 \mathrm{He}$ is a man of many excellencies, of many benevolent: and tender feelings, generous soul and of very general knowledge. Preached several years in Brownville $\mathrm{N}$ [ew] York-graduated at Union College where was Tutor, studied divinity with Dr. Nott. Was the first: Protestant minister in Detroit [95] and Pastor of First Presbyterian Church there 12 years-it was thought he had an aneuism of his heart and was obliged to cease preaching. This has proved a mistake, but his constitution is shattered and has to be very careful of himself. He took off a few years since at once from an excessive and constant use of tobacco. He describes his sensations at that period as painful and distressing in the extreme, and as nearly making him delirious, but now he has no hankering for it. Is fond of sporting, kills squirrel and pigeons. Was brought up to trade of a saddler. Mr. Lockwood, Eilder of Presbyterian church at Prairie Du Chien and brother of Mr. Iockwood of Dubuque (p. 34) came over with Mr. Wells. Manifests an interest in every good work.

Had a Temperance meeting at Jacksonville [on] Aug. 31 at which Mr. Wells and self madc addresses.

Mr. Mason Noble, 98 lawyer, native of Mississippi, lived in Grant Co. W. T., a growing young man, intelligent, a desire of popularity leads him at times astray from the path of high morality, expresses an in-

90Called Prairie Litporte Post Ofice in 1830, name changed to Jacksonville, December 12, 1843, and to Garnavillo, May 27, 1846 .

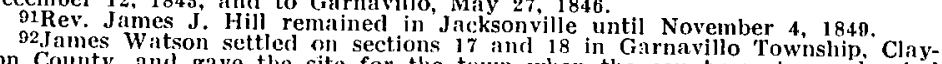
ton County and gave the site for the town when the county seat was jocated at Garnavilio.

93.Jolin M. Gay and wife. Saralı.

94 Nancy J. Gay and Mary Gay.

95 Alfred Kinney and Mrs. Penely Kinney

96 Hugh L. Kirkpatrick of Potosi, Wisconsin.

or Ezekiel 18:31. Cast away from you all your transgressions, whereby ye have transgressed: and make you a new heart and a new spirit: for why will ye rlie, 0 house of Israel? 98 There was an attorney, Reuben Noble, who came to Jacksonville in 1843 ,
but I find no Mason Noble. 
terest in the general work of society-of gentlemanly manners-married this summer, his wife from neighborhood of Alton. [96] Dr. Andros ${ }^{99}$ from Mass. a wicked man-gentleman, kind-hearted, his father a Congregational clergyman yet living. The Dr. has a boy named after Dr. Storrs of Braintree[?] Mass. Mrs Andros more of a lady in her appearance. Mr. Whitman a promising young man. Mrs. Kinncy had a son baptized whom she named after Br. Hill.

Mondiy, Sept. 2. Went to Prairie Du Chien with Mr. Wells, I.ockwood, Hill and Mrs. Hill thru a beautiful prairie country, well timbered, which must in a few years be thickly settled. Prairie Du Chicn presented a beautiful appearance from this side of the river as the rays of the setting sun were reflected from the garrison and other neat white buildings, crossed in ferry boat landing at the lower townspent the night with Mr. Lockwood's pleasant family, Mrs. L.[ockwood] a second wife. Thursday morning visited the garrison. ${ }^{100}$ Mrs. Welis, a second wite, very much discontented, native of Hudson $\mathrm{N}$ [ew] York. A Miss Salter from Philadelphia has been visiting a sister (wife of Licut. - - ) in the garrison this summer. She is now visiting a brother Dr. S[alter] at Moline, Ill.

Mr. Wells was well acquainted with Mr. Gale (now of Galesburg, III.) Finney, Burchard, thinks if Mr. B. [97] had enjoyed the benefits of a good education he would have made one of the most eminent ministers in our country-or it may have been that a good education would have inflated his vanity and ruined him. Mr. Finney has been an opposer of religion and when he pretended to be under religious impressions pious men, thought he was making fun of them and begged him to desist until in admiring wonder of Divine Grace they were compelled to ask "Is Saul also among the Prophets"?

The Father of Mr. Cleary of Beloit (p. 91) was a pious deacon, old school and opposed to new measures and protracted meetings-a revival was in progress and he did not come to the meetings. One day while harvesting his oats his feelings changed, he drove to meeting and after [the] sermon told the people that if he ever experienced religion he did it that day in his field. The revival went on powerfully-it was reputed that the old deacon had given up his old hope and obtained a new one. But, explained the Deacon, I said if I ever experienced religion I experienced it again.

Mr. Wells is very sociable and has a fund of infor- [98] mation on all subjects.

'Tuesday Sept. 3. [I] crossed the Wisconsin at Burnett's[?] Ferrysaw a Frenchman tho [a] native of Canada who has been there 26 years-dined at Patch's on [the] Ferry (where they have been settled

90Dr. Frederick Andros is said to be the first settler in Garnavillo Township. locating on the nortliwest quarter of the southeast quarter of section 20, towi]ship 93 north, range 3 west, in January 1836 . He moved to McGregor in 1865 , and later to Mitchell, Dakota. Vid. Interstate Publishing Company, The History of Clayton County, Ioux (1882), p. 786 .

100For a history and description of Fort Crawford, vid. Bruce E. Mahan, old Fort Crawford and the Frontier, Iowa City, 1926. 
nine years), rode to Lancaster ${ }^{101} 20$ miles. Br. Lewis preached from Heb. 2:3102 [on] The Great Salvation. There not being a quorum present of [the] Mineral Point Convention, Convention adjourned to Platteville [on] Oct. 2. Enjoyed hospitality of Mr. Mills (p. 71).

Bro. Stevens and Lewis were united [in the judgment] that I ought to go to Potosi. Br. Rice informed me of the strong desires of the church in Potosi that $I$ should come there and of their proposition to support me independently of the A. H. M. S., but as I have regarded the advice of the A. H. M. S. as an indication of Divine Providence, I could give no encouragement. I learn that Rev. Mr. Kendall of [the] last class at Andover is coming into [the] Mining region, and I strongly recommended him to $\mathrm{Br}$. Rice, and hope he may go to Potosi. Mr. Holbrook has a call from [the] church at Mineral Point-he postpones his decision until his return from the East.

Arrived at Dubuque Sept. 5-found Mr. [99] Lancaster (from Missouri) and Springficld and Jacksonville, Ill.) a Campbellite preaching in [the] Presbyterian church to a large congregation. He has formed a church. Mr. Mobley, Cashier of Miner's Bank of Dubuque, [is] the pillar of the society. Mr. Lancaster was a Methodist Prcacher, a fluent speaker, powerful voice--he succeeded in gaining the itching ear of Dubuque.

Spent a few hours with Mr. Kent day before yesterday, Sept. 10. He expresses concern for Potosi and doubt as to the question of my duty to go there. He suggested the probability of Mr. Holbrooks going to Mineral Point and in that case the expediency of my supplying Dubuque. $O$ that the L.ord may guide our steps.

'The Lord's hand is on me for good, preserving me from dangers seen and unseen. I am under first obligations to be entirely devoted to the work of the L.ord-in His providence the door of Wisconsin scems to be shut against me. I will trust in the Lord, and by his grace do good.

The people at Beloit and Picitonic have professed to subseribe very liberally if the $[100]$ seminaries are located in their respective villages. $O$ that we had such a population in Iowa. At these places they engage to put up a suitable building at cost of about eight or six thousand dollars.

In Dubuque made the acquaintance of Mr. Franklin Knight of Washington. $\mathrm{He}$ is a publisher of facsimile copies of some of General Washington's papers and is travelling to sell the work. He was the first publisher of the L.iterary and Theological Review, edited by Leonard Woods Jr. ${ }^{103}$ He says an article by Br. B. B. Smith of Kentucky on

101The plat of Lancaster was recorded May 1, 183\%. An excellent description of the Wisconsin territory over which Mr. Salter traveled at various times may be found in Rev. Alfred Brunson's. "A Methodist Circuit Ricler's Horseback Tour from Pennsylvania to Wisconsin, 1835," in the Wisconsin Historical Colections, Vol. XV, pp. 264-291.

102 Hebrews $2: 3$. For if the word spoken by angels was stedfast, and every 103Franklin $\mathrm{Knight}$ publisher of the a just recompence of reward.

by Leonard woods, Jr publisher of the Literary and Theological Review, edited Magazines (1830), pp. 624-625. sketch in F. L. Mott, $A$ History of American 
Christian Union was extremely injurious to the circulation of that work. He disposed of the work soon after Pres. Woods left the editorship of it. Mr. Knight mentioned that he called to see Pres. Woods at Brunswick this last spring, and asked him in relation to his true position with regard to the rumors abroad about his Episcopal Romanisticl?] motives-You know me and my opinions, replied Pres. Woods, when we conducted the l'heol[ogical] Review, and my opinions are as they then were.

Mr. Knight has heen Assistant Secretary of the American Colontzation Society, and informs me of a division in that Society between the friends of Mr. [101] Greeley and those opposed to him which resulted in the election of a new Secretary. Elliott Cresson[?] of Philadelphia was at the head of those opposed to Mr. Greeley, Mr. Knight thinks that Mr. Cresson is not actuated by a henevolent spirit, but is selfish entirely in his views and protestations.

The friends of Mr. Greeley organized a new Society, "Society For The Colonization and Civilization of Africa In 'The District Of Columbia And Maryland." Mr. G[reeley] is Secretary. Its funds are mostly paid to [the] American Colonization Society. Mr. G[reeley] has been the great pillar of the cause of African Colonization-had he now abandoned or opposed this cause, it would have fallen-by this new organization his friends who are very numerous, especially at the South, are retained to the help of this world cause.

Mrs. Davis (sister of Mrs. McCloy) passed this house today on her way East. She has lived in Toledo, Ohio, a very pleasant lady-expresses much interest in and for the work of the I.ord in the West.

Sept. 13. I have become acquainted with Mr. MeCuen [sic $]$-a native of Greenfield, Saratoga Co. N[ew] York but moved to Canada when a small [102] boy-lost his parents-was a horse boy on the Welland Canal-had no education, when 18 years old could not readlearned blacksmith's trade, was converted and educated himself, and is a very intelligent man, of generally good judgment, of natural talent, has a fluent and ready command of the English language, has lectured on 'Temperance in Lockport, N[ew] York, Freeport and Galena, III. Has lived this summer with his brother on 'lete Des Morts where [he] was sick. Has spent about a month in Mr. Parmely's[?] family. His wife (native of Canada) has been quite sick. They buried an infant child last week. Mr. McCuen is moving to Makoketa and will spend the winter with Mr. Chandler's family, near Doan's.

Sept. 19. Saw old Mr. Herrington last Sabbath. He was a native of $\mathrm{N}[\mathrm{ew}]$ Hampshire near Keene, moved to Montpelier, Vt. His wife pious from her youth. Spent one year with his son near Bellevue ( $p$. 25) and was very sick. Has a son in Burlington, Vt., some children in Ohio-is undecided where to live himself-seems to be a good simplehearted, candid man, attended a 40 days protracted meeting of $\mathrm{Mr}$. Burchard in [103] Vermont. Visited yesterday Capt. Silsbe[?], a man of very disagreeable appearance and manners (p. 43), gave him two 
$\aleph[e w]$ York Observers, called at Mr. Sawtell's, Mrs. S[awtell] thinks she is a great deal better than most who profess religion and is well enough off. Called at Mr. Hawkin's who is living in Mr. Sawtell's old log house. [He is] from Mercer Co. Penn. Mrs. H[awkins] has been for three years a member of the Presbyterian church (O[ld] S[chool]), has nine children, William (aged 14) a pleasant boy. Attended last evening a prayer meeting at Mr. Knapp's. Mr. Whittemore (a brother of Mrs. K(napp]) was present, a Baptist Preacher from Maine arrived this week. Commenced preparing for the ministry rather late, studied at Helvor [sic] Academy and Baptist Seminary at West Thomaston, Maine. 'loo close application injured his health. [He is] of pleasant manners and good intelligence. His mind seems to be a good deal under the influence of religious truths-he designs settling in the county if Providence opens a prospect of usefulness before him, spent the afternoon with me.

Cottonville, Sept. 24. Spent the last Sabbath in Dubuque-enjoyed the hospitality of Mrs. Bissell. She was of the Lansing family in L.ansingburg, $\mathrm{N}[\mathrm{ew}]$ York, an intelligent [104] lady, of refined habits. An interesting family of children, Mary, Helen, Anna, and Henry. Mrs. B[issell] has generally Roman Catholic servants in her house. She had one who was kind hearted and attached to her family, but very ignorant. 'There having been at one time much talk about. Mr. B [issell's] being opposed to the Papists, Mr. B[issell] asked this girl what the Bishop said in relation to her family-the girl somewhat reluctantly told her, that the Bishop said that Mrs. B[issell] was a good woman but he wished she was a Catiolic-and the girl then asked Mrs. 13[issell] if she would not read some of the Bishop's books if he would send them to her. It is plain that this idea could not have originated in the mind of this ignorant woman, but must have been suggested to her by the Bishop.

'The Bishop calls on Mrs. B [issell] and always to see the children. Jno. Foley is a clerk with Mr. Bisscll, a very steady and upright youth, and [in] religion [is a] Papist. Mr. Evans, a native of Wau [wic] $\mathrm{N}$ [ew] Hampshire clerks with Mr. Bissell.

On my return called on Mr. Carson and Foley who live on the East side of Flint Hill. Mrs. Foley was by $[105]$ birth a Protestant, but now a bigoted Papist.

Called on Mr. Montague, native of Vermont, raised in West Hampton, Mass., moved to Chautauqua Co. N[ew] York, [is the] brother in law of Mr. Palmer at Andrew. A Baptist, grood man-seemed interested in advancement of society-has considerable self-esteem and knows as much as anyone.

Sept. 26. Visited yesterday Mr. David Young (p. 24) (p. (64) a pleasant visit. John, the oldest boy was aged 15 in Feb. last. The excessive rains and freshlets this season have hindered Mr. Young in building his mill. The water was at one time all over the bottom on which his house is built and to the middle of the lower story of his 
mill. Mr. Elwood, a Methodist from Pennsylvania, carpenter, is working there, [he is] an intelligent young man.

Mr. Buck is a very amiable and interesting young man. His father in Pennsylvania [is] a very pious man in the Presbyterian church (N [ew] $\mathrm{S}$ [chool]). 'Ihis young man is a hatter by trade [and] has a claim West of Gen. Cubbage's. Mr. Young has a brother John, a smart man, eloquent speaker, warm-hearted abolitionist, [who] desires to come West. Of a similar character is Mr. Davidson (in Ohio) a brother of Mrs. Young.

Mr. Whittemore (p. 103) preached here (Deacon Cotton's) last evening on Christian Character., [from] 2 Cor. 5:17.104 His sermon [196] was neatly and systematically prepared and in good taste.

Sept. 28. Finished yesterday a sermon calculated for the latitude of our General Association. It is the first sermon I have written out since I came West. I notice the effects of my habit here in the carelessness of my style. Modes of expression which a year ago I would not have tolerated, now are spontaneously put on my paper. Still I experienced some gratification when the task was completed.

Brighton, Washington Co., I. 'T. Oct. 4, 1844. Mr. Whittemore (p. 103) preached for me last Sabbath at Andrew. An attendance of 4.0 . Monday Sept. 30 left Maquoketa for meeting of General Association at this place, came by way of Alger's Ferry, Allen's Grove, Hickory Grove, (in the South end of which spent the night with Mr. Porter[?] member of Baptist Church in Davenport, from Muskingum Co. Ohio. [He is] an intelligent inquiring Christian. His sister was seriously injured in the hurricane in June (p. 83) the house (Mr. Baker's), she was in [danger of] being blown down and [at] Blue Grass Point and Bloomington where [I] enjoyed the hospitality of $\mathrm{Mr}$. Robbins. Bloomington is improving, much building going on. A meeting house for $\mathrm{Br}$. Robbins' congregation [is] going up at [a] cost of 900 dollars [107] was introduced to Mr. Brownell. Wednesday morning (Oct. 2) started in company with Brs. Robbins and Hitchcock for this place, came by way of Fredonia, Columbus City, Louisa Co., and Washington. Mr. I.ucas, delegate of the church in Bloomington, came along [he is] from Ohio, an intelligent and active Christian.

Fredonia is at the forks of the Cedar and Iowa rivers-where is [a] steam saw mill and ferry. Columbus City is two miles below on [the] prairie-a few good dwelling houses, but no trade, nothing to build up a town. Washington, the county seat of this county, is a pleasant prairie town. The Court was in session, became acquainted with Judge Williams, ${ }^{105}$ a very sociable companionable man, full of talk-of very little dignity of character, polite and gentlemanly. I should judge had a good mind, and clear discernment of the relations of things. Was

104 II Corinthians 5:17. Therefore if any man be in Christ, he is a new creature: old things are passed away; behold, all things are become new.

105Joseph Williams, associate judge of the Supreme Court. Vid. Edward $H$. Stiles, Recollections and Sketches of Notable Lawyers and Public Men of Early lowa (1916), pp. 37-45. 
introduced to Mr. Hall,106 lawyer of Mt. Pleasant, self-educated man, of no religious character, of high standing in his profession, a delegate to Convention for forming a State Constitution, [I] reached this place Thursday Oct 3 at $91 / 2 \Lambda$. M. when found many of my brethern assembled. Br. Gaylord [is the] Moderator of this Association. Resolutions werc adopted on Sabbath School Librarians, Slavery, the Sabbath, the Political destinies of Christians, the establishment of a $[108\}$ newspaper (to Adrocate the causes of Morality, Freedom, Education, Religion etc) and on the Bible cause.

An interesting discussion was held on withdrawing Church fellowship from slavelsolders. Brs. J. A. Reed and Spaulding and Julius Field (agent of A [merican] Bible Society) [were] against such action.

Oct. 5. Report of the state of religion was attended to. 120 members in Church at Denmark, where [they] are erecting a brick meeting house. Br. A. 'Turner reported the death of Mr. Abner Kneeland $[$ ? of fever about four wecks ago. Mr. Houghton (page 4) riding by with his wife one aftemoon called at Mr. Ks-went in, and tho told that Mr. K. was doing pretty well, found his extremities already cold. He seemed to be in $\mid$ an $\rfloor$ unconscious stupor altho on being aroused he recognized those around him. He died early the next morning. The Secretary of Mr. K. died about two years ayo (Mr. Twombie), swearing and praying by turns on his death bed.

The infidel influence in Washington is declining. Mr. Sturgess[?] the delegate of the Church there is an interesting and intelligent young man, was a memher of Wabash College with Mr. Fathers, has taught school. Mr. White, delegate of [the」 Ch[urch] at Louisville, County seat of Wapello Co., [a] native of Amherst, Mass., lived at Alton and acquainted with Br. E. B. 'lumer, expects to teach a school this winter. [He is] an intelligent gentlemanly man.

[109] Br. Spaulding reports a [Fourier?] Association on the Des Moines in Mahaska Co. among whom he has preached once or twice.

Eddyville is the largest settlement in Wapello Co. where [there」 is a neat meeting house erected by one man for any and all denominations. Mr. Woodworth of [the] $\mathrm{Ch}[\mathrm{urch}]$ at Crawfordsville, a decided Anti Slavery man, from Warren Co., N[ew] York, where. [he] was acquainted with the Wrights at Maquoketa.

Only one half of our Andover Company viz. E. Adams, Lane, Robbins, Spaulding, and myself are present.

Br. Jagger, [a] native of Southampton, Long Island, his daughter, who has unfortunately lost her reason, the wife of Dr. Burham, of [the] Danville Ch[urch] [is] a warm hearted Christian, and a brother of Rev. Mr. Gaylord, [a] native of Norfolk, Conn't. of church under [the] care of Dr. Emerson, now of Andover. Yesterday afternoon there was a Council held called for [the] installation of Br. Burnham ${ }^{102}$

10sJonathan C. Hall, together with four other delegates, attended the Constitutional Convention in Iowa City from October 1 to November 1, 184.4.

jor Rev. Charles Burnham. 
over the Church here. Br. B [urnham] was converted in 1927, he makes a faithful minister.

On the subject of a newspaper $I$ thought one of a religious character to be sustained by our people in Wisconsin, Northern Illinois and Iowa desirable and feasible. But our brethren think we must have one peculiarly for Iowa and of a more general character, tho I doubt its success.

['The] Iowa College Association met and Rev. A. Turner, Agent, presented his report. In Boston he met with the friends of the Society for promoting Collegiate [110] and theological education in the West who advised the abandonment of the plan for establishing a College by a colony and lands, $[s i c]$ and then concentrating eftort at some important point. The friends of that Society assured our Agent of its patronage so soon as we had started things in a proper train. Our College Association appointed E. Adams, A. Turner, and Boal a Committee on location.

Have enjoyed here the hospitalities of Mr. Washborn. ${ }^{108}$ Mrs. W/ashborn] a very pleasant woman, [and is a] member of the Church here, has two boys, about 15. Mr. Beach, Mr. Waters, Mr. Hart, Moore, Bushnell and Ingham[?] are interesting families in the Church.

Cottonville, Oct. 15. On return from [the] General Association came thru Washington and attended (Oct. 8) [the] first Annual Meeting of the Iowa Anti Slavery Society. Aaron Street, Jr., ${ }^{109}$ President, of Salem, a Quaker, of plain unassuming manners, [and $\mathrm{Wm}$. Lewilling, ${ }^{110}$ Recording Secretary. Mr. Jessup, Assistant Secretary, both of Salem. Mr. Vincent, ${ }^{111}$ minister of Seceder[?] Church in Washington, of prepossessing appearance, an able preacher, Mr. Anderson, member of Seceder Church lives $1 / 4$ mile north of town. Mr. Balis, Quaker, from vicinity of Indianapolis, was present. There seemed to be the prospect of a harmonious and serviceable meeting.

[111] Came over dreary prairie to Iowa city (30 miles) crossing English river at McClun's mill. Called on Br. Woods'12 and took dimner. Attended session of the Convention for forming a Constitution. $\mathrm{Mr}$. Leffler ${ }^{113}$ of Burlington presided with dignity and fairness, but few old men in the Convention. A large majority voted to lay on the table a resolution for having the meetings opened with prayer. There are some competent men in the Convention but the greater number are ignorant and poorly qualified.

Came up on the Military Road to Cascade (60 miles) where [I] addressed the Temperance Society and came to Makoketa by way of South Fork Mill where called on Mr. Cook's family.

Found Br. Woods at Iowa city very favorable to a union of Pres-

108L. G. Washborn, and wife, Elizabeth.

109Aaron Street, Jr., in March 1839 helped lay out the village of Salem and was the first postmaster.

110 Also a Quaker.

111Rev. Cieorge C. Vincent. Vid. Union Historical Company, The History of Washington County, Iowa (1880), p. 433.

112Dr. W. W. Wood of the New School Presbyterian Church.

1i3Shepleerd Leffler. For biographical sketch, vid. Stiles, op, cit., p. 119. 
byterians and Congregationalists in Northern Iowa. Became acquainted there with Mr. Andrews, a young Scotchman, tailor, intelligent, warm hearted, Anti Slavery.

Association passed a vote requesting Gov. Chambers to appoint a day of thanksgiving, and in case he should not appoint one designating the last Thursday in December a day of thanksgiving. Association appointed me [112] delegate to General Convention of Wisconsin and Br. Hitchcock [as] substitute. A. Turner, E. Adams, and Salter were appointed to correspond with $A$. H. M. S. and desire the appointment of Rev. J. S. Clark (in case Mr. C. would consent) their agent in Iowa.

Oct. 18. It has snowed nearly all day-very cold for this season.

Oct. 30. The Northern Iowa Association met at Cascade Oct. 23d. In consequence of the non attendance of Dr. Woods nothing was done in relation to a union of Pres. and Cong. in Northern Iowa. Mr. Philip Bevan ${ }^{144}$ of Charleston was licensed to preach for six months. [The] 24th inst. came by Romish Church in the Irish settlement to Mr. Alexander's on Lytell's creek. Saw Mr. Brown, a young man from North of Ireland, where [he] was raised in a Presbyterian Church, seemed a good man, and is desirous of uniting with this Church.

With $\mathrm{Br}$. Asa Turner commenced three days meeting on Friday evening at Andrew. People gave good attendance. Mr. Young and family and Mrs. Margaret Means united with this church. Mrs. Bradley,,$^{115}$ Caroline Davis, G.[?] Butterworth,110 Sarah Ann Cotton, Juntha[?] Hadley, Mr. Palmin's daughter and Robert Reed expressed themselves determined [113] to serve the L.ord. There was much feeling in the congregation.

Subbath afternoon I rode to see Mr. Rice but the Doctor (Clark) ${ }^{117}$ and his friends were unwilling that my conversation should be held with him, and yesterday I learned that he died on Monday morning. He hatd been a member of [the] Methodist Church in the East, became careless and worldy and then had thrown off the restraints of religion. Six Sabbaths ago I met him with Mr. Cheney's [?] boys as I was riding to meeting from Deacon Cotton's to Andrew. I invited them to go to meeting with me but they replied they were going to meeting at Montague's. I learned afterwards that they went to gather hickory nuts and that Rice in throwing a club into the tree strained himself and was seized with a pain in his side. He afterwards exposed himself, was laid upon a sick bed and is dead. Dr. calls his disease an ulceration of the liver.

Have enjoyed very much the visit of Br. Turner (p. 4). Familiar acquaintance with him has increased my appreciation of his worth.

Nov. 16. Visited Br. Holbrook this week who returned [on] 8th inst. from the East, he raised some 800 dollars [114] for the Church

114Vid. Philip D. Jordan, "Philip Bevan-Minor Poet of Ohio," in The Ohio Archaeological and Historical Quarterly, for April 1931.

$115 \mathrm{Mrs}$. Philip P. Bradley. Vid. Western Historical Company, The History of Juckson County, Iowa (1879), p. 725.

117Dr. M. H. Clark, said to be the first resident physician of Andrew. 
in Dubuque, expenses about 150 dollars. He has a call to settle with $\mathrm{Ch}$ [urch] at Mineral Point, the A. H. M. S. advise his remaining in Dubuque.

Dec. 4. We had four days [of] cold weather commencing on the 23rd November. Have observed Monthly Concert and much interest has been manifested, have sustained for the past few weeks a weekly prayer meeting.

The land sales advertised for January next are causing much excitement. Settlers are clubbing together to protect one another in claims of half a section, if they make out in this the effort will be to keep out settlers and prevent, or postpone the time of a good settlement. Rev. Horace Eaton, Baptist, aged 33, from $\mathrm{N}[\mathrm{ew}]$ Hampshire, studied at N. Hampton Baptist Seminary, has preached in Bedford, N. H., came into this neighborhood this month, of pleasant mamners [and] solid substantial character, [has] been three years in the min.stry.

Dec. 13. Observed yesterday as a dayy of national Thanksgiving, according to recommendation of Gov. Chambers. ${ }^{118}$

J. Billiom [?] became acquainted with Mr. Trott [1]5] from Boston, a descendent on his mother's side from Gov. Winslow, (where attended Old South Church) and $\mathrm{N}$ [ew] York where was member [for] eight years of Central Presbyterian Church. An active intelligent man and may become a useful one. Mrs. Trott, an intelligent lady, daughter of Mr. Whitney, Keeper of public house at Niagara Falls. She is a Universalist. Is rather close and I fear will not be popular in the west.

Visited Dec. 21st Mr. Harris on Farmer's ereek, He was a native of Bridgton, N[ew] Jersey. His mother an Episcopalian. [He] has lived in Missouri and near Galena, came into this country in the fall of 1834 and settled on what is now Mr. Boone's claim. Indians were thick, he had no neighbor nearer than Mr. Baker one mile from Bellevue. Mr. Harris and Mr. J. S. Kirkpatrick and Mr. Potter are elders in this Church. They have over one hundred members. Mr. Harris seems to have much of the spirit of Christianity, a kind disposition, an active inquiring mind, preaches every Sabbath.

Jan. 8, 1845. The Maquoketa 'lemperance Society held its annual meeting Jan. 1. It now embraces about 100 members, [with] H. G. Haskill, President, W[illiam] S[alter], Secretary. It was voted to petition the County Commissioners to grant no licenses for a grocery for any sum less than one hundred dollars as anthorized by law. I circulated a petition of a similar character about Andrew and got some fifty subscribers. The grocery keepers [116] were offended thinking their craft in danger and have got up a remonstrance.

A Baptist $\mathrm{Ch}$ [urch] was organized at Andrew [on] January 5 by Rev. H. Eaton consisting of nine members. Deacon Montague and wife, Mr. Palmer, Mrs. Knapp, Mr. Franklin, Mr. Mark and three others, [were present]. Mr. Harding was present, [he is] a Baptist Preacher who lives S. W. of Bellevue.

118Vid. Shambaugh, op. cit., Vol. I, pp. 309-310. 
[On] Jan. 6 a meeting was held in Andrew of citizens of the county for the protection of one another of claims of half sections of land until 1848. There was a large collection of people and a deep intention manifested in securing possession of their lands.

Jan. 19. There has been great excitement thru this county the past week. Many of the settlers were on this road or about being on the road for Dubuque, but on 'Tuesday news came that the land sales were indefinitely postponed. Many are disappointed, some are glad. I regret the postponement because this excitement will all have to be gone over with again, the settlement and improvement of this country will be retarded.

Feb. 5. Visited Mrs. Reed (Mrs. Van Horn (p. 27). She married [117] last summer, and being disappointed, I fear, and sick, her mind has lost its proper balance. Very melancholy case. Visited in the Buckeye settlement. They have a good school there this winter taught by Mr. Hunter from Cortland Co. N[ew] York, who is a Methodist. His parents [are] O[ld] S[chool] Presbyterians and live up Deep creek. There are ten schools kept in Jackson Co. this winter. Visited Mrs. McFarland who is living in Jno. Jonas' house on Copper creek at his diggings. She was [a] member of [the] $O[I d] S$ [chool] Pres[byterian] Ch[urch] in Alleghany Co. Penn.

On this Prairie six miles beyond Dunham's visited Mr. Hall from Jackson Co., Mich., and from Vermont, and his son in law Mr. Richardson. There will probably be a settlement about them on the head of Sugar creek in a few years. Mr. H[all] was brought up among Congregationalists and desires to have meetings.

Visited Cascade last week. Found Br. 'Turner rejoicing in the conversion of sinners. This work commenced on Whitewater where was a powerful awakening. The revival obtained on Bowen's prairie, but none in town were converted, tho there were cases of awakening. $\mathrm{Br}$. Holbrook's preaching was in [118] power. Two[?] Mr. Pate and wifes, Mr. MeGinty and Mrs. Boyd united with the Church on profession. Mr. McG[inty] promises to be a stable useful man. Mrs. Jemsha Jackson united with the Ch[urch] by letter from [the] Ch[urch] in Dubuque. She was [a] member of Brainerd $\mathrm{Ch}[\mathrm{urch}], \mathrm{N}[\mathrm{ew}]$ York, a lovely woman, bright, intelligent, and of apparently living piety. $\mathrm{Mr}$. Jackson [is] a pleasant affable Kentuckian. They live on the South Fork in Delaware Co.-fifteen miles from Cascade. Mr. J[ackson] says there is a good chance for a large settlement about them, there being: timber and water power.

Mrs. Leek united by letter from [a] $\mathrm{Ch}$ [urch] in Ann Arbor, Mich. She is a sister of Mr. W. S. Brown, lately of Andrew and Judge of Probate of this county. Mr. Leek is a very wicked man.

Mr. Livingston of Upper Scotch Settlement from [the] Red river froze to death on [the] prairie Fridayl?] last, above Cascade. He was of intemperate habits.

Came home yesterday by way of Saw Mill where they are doing 
considerable business and about laying off a town to be called "Canton".

$\mathrm{Br}$. Turner cautioned me some blunders of rhetoric and elocution into which I [119] have fallen, Oh [sic] tempora! O mores!

Feb. 27. Bishop Loras of Dubuque told Mr. Hubbill of Charleston that if he would give his son who is idiotic in mind and helpless in body, aged 10, to the Church he would cure him but that if he should take him away from the Church his diseases would return. How disgraceful [is] the attempt to promote superstition in this 19th century.

Visited [on] Feb. $10 \mathrm{Mr}$. Gray at Savannah. He came there last fall, was a member of Genessee Presbytery, $\mathbf{N}[\mathrm{ew}]$ York. Was opposed to. ecclesiastical action against Oberlinism for which was regarded by some as a Perfectionist. Is Anti Slavery. Has lectured on Temperance with Sewell's plates. Says that Dr. Lord when in $\mathrm{N}$ [ew] S[chool] Presbytery was the leader of action against Oberlinism. Mr. G[ray's] health is rather feeble. His wife [is] a pleasant lady. Prospect at Savannah is not very encouraging.

Mr. Bevan at Charleston thinks of studying entirely, and of moving into town which Br. Emerson recommends.

The ice went out of the Mississippi at Charleston [on] Feb. 19th.

Deacon J. Jenny[?] called on me this morning. He is [a] member of Br. Adam's Ch[urch] in Davenport, was from Chester, [120] Vermont. An intelligent man. Apparently of sterling character.

March 1. The past has been a very mild winter, but few cold days -no snow of any consequence. It was predicted last fall from the number of bears [or beans?] that it would be a cold winter.

The following schools have been kept in this county this winter, at Maquoketa by Mr. White and Mr. Stern[?],119 in [the] South Settlement by Mr. Mears, Burleroin[?] S[chool] H[ouse] by Mr. Davis, Copper creek by Mr. Hunter, Charleston by Mr. McIntyre, Bellevue by Mr. Anson Herrington, Andrew by Mr. Hindman, Farmer's creek by Mr. Tyson, in the Forks by Macaulay, Germain's S[chool] H[ouse] by Mr. Whittemore, ten schools.

The first steamboat at Dubuque this season was thru March 1st. (p. 47)

March 20. Visited Br. Holbrook last week. There is a little interest in a few minds in the claims of religion. He expected Rev. Z. Eddy of Mineral P't. to preach for him this week. 'This church is about erecting a house of worship at [a] cost of 2000 dollars-came here [on the] 15th thru a snowstorm as [121] far as Deacon Cotton's-rode to Dewitt last Sabbath morning, administered the ordinance of Baptism to Mrs. Frances Work [and] returned yesterday which was a very severe and blustering day.

March 24. On Thursday last after attending the funeral of Mr. Marshall a newspaper came from Bellevue informing me of the death of Mrs. Jennings (p. 38). Mrs. J [ennings] was from Burlington, Ver-

$119 \mathrm{Mr}$. Steen was disliked and taught only about a month. 
mont, aged 22 in July last. She came here in Nov. 1843 in the bloom of health. She possessed a firm person, an intelligent mind, a kind heart and engaging manners. She was lovely and pleasant in her life. She was an affectionate wife. There were but few females in the county I esteemed more highly. She felt most interested in and sympathized with my efforts. She gave promise of leading a useful life. But God has called her into the eternal world. She left a little son now three months old. She died of craniall?] debility. She suffered from ague and fever last fall, took cold after her confinement and gradually sunk away. Her friencls and myself thought she would recruit with the return of warm weather but God destroys the hopes of man. The Doctor's cross is very great and Bellevue seems to hold but [122] little of any worth now that she is taken away. I saw her about the middle of February. We camc into this County about the same time. She is taken, I am left.

March 28. Attended Mr. Howe's funeral at Bellevue yesterday. He was present at Mrs. Jennings funeral on Friday last and seemed as fair to live as any one present. He was a man of bad habits which had subjected him to attacks of pleurisy. This was his fourth attack. He was under the influence of liquor when attacked. By nature he was a kind, clever, smart man. but [he] destroyed his property and character by intemperance. He left a wife and two small children.

April 8. Visited 'lete Des Morts [on] March 31st. Called at Stevens; Mrs. S[tevens] [is] a daughter of Cheney. Says she is a Restorationist, a conceited woman. Had an interesting conversation with $\mathrm{Mr}$. Potter. He seems to be converted, he is naturally diffident, he engaged in prayer. His two boys, Nelson and Philip, need education. Visited Mr. Milner[?], brought up in $\mathrm{Ch}$ [urch] of England, his wife formerly a Methodist, but now disaffected, [and also visited] Mr. Brown's and Kelley's family. Mr. K[elley] recently [123] lost his only boy. His

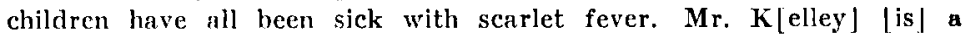
sister of Mr. Potter. Mr. P[otter] [is] from Floyd, Oneida Co., N[ew] York. [I] visited Galena [on the] 2nd inst. when [I] gave [a] lecture on Education-made the acquaintance of $\mathrm{Mr}$. Geo. F. Magoun ${ }^{120}$ from Bath, Maine, graduate of Bowdoin, studied Theology at Andover and $\mathrm{N}$ [ew] Haren. Mr. M[agoun] has made himself well acquainted in the cause of Education and is enthusiastically interested in its advancement, is a man of warm, ardent feelings, clear understanding, benevolent soul and Christian affections-a great addition to our moral and religious influence in this region. I trust Divine Providence will open a wide door of usefulness to him. [I] became acquainted with Mr. French, a gentlemanly, intelligent Frenchman, has been engaged in Teaching 30 years. A Catholic-says the Romanists would rather not have the Bible read in schools, because it will be making it too common a book, but that if the Bible be in schools that the children read the

120Rev. George F. Magoun, author of Asa Turner and His Times. Vid. Douglass, op. cit. passim. 
Douay [?] version. Mr. French is an exceedingly polite gentleman. I shall [124] be glad to propend[?] his acquaintance.

Took tea with Mr. Bitter in Galena. He is a native of Saco, Maine, and owns town property at Bellevue, [and he] desires [the] establishment of a Congregational Church there, for which [he] offers to give a lot for House of worship.

April 14. The last month has been very dry and pleasant, no rain for four weeks, fine showers this afternoon.

Alonzo Spaulding has I trust been lately brought to the knowledge of the truth as it is in Jesus. He appears humble and prayerful and determined to live as becomes a child of God. The name of the Lord be praised.

April 17. Mr. Barnett has been in to see me this evening-raised in Washington Co., Vermont near Montpelier, aged 26, thinks he was converted seven years ago and united with Methodist Church in which [he] was brought up, is a serious minded industrious young man, lived in Apple River diggings some months, came into this neighborhood last fall. He gives promise of usefulness.

April 21. Visited Sabbath School in South Settlement yesterday afternoon, 36 scholars present, a pressing want of 'Teachers.

[125] May 3. Visited [the] 1st instant a mill site three (21/2) miles below Doam's, where on [the] South side of Maquoketa the bluff comes to the river and on the north side there is a bank four feet above highest water, in company with Gen. McDonald and Thos. Cox. (p. 29) [It will take] considerable labor to put in a secure dam. There is a large body of iron ore two miles north near Watkins. Mr. Watkins was raised near Richmond, Virginia, lived in Westbury[?], at St. Charles, Missouri. Drinks badly at times.

May 5. Yesterday [was] a very beautiful Sabbath [and I] had a congregation of 60 in the morning. A Educational meeting this evening which was addressed by Mr. Decatur.

May 10. Northern Iowa Association (p. 14) met at Albany, Whiteside Co., Illinois, 6th inst.- a very interesting and profitable meeting. In crossing the Mississippi [we] were in imminent peril of being drowned in consequence of high winds and waves and leaky boat. If it had not been [for] the Lord who was on our side we should have dwelt in silence. Br. A. B. Hitchcock makes a good business moderator. Became acquainted with Mr. Smith of Lyndon, was from Otsego Co., $\mathrm{N}$ [ew] York and Oberlin, [126] a plain, practical, common sense, clear mind, an interesting speaker, rather opinionated.

May 29. Returned last evening from a missionary tour round the county, visited twenty-five families.

Mrs. Forbes on Brush creek, one mile from Andrew, has a brother, Mr. Trowbridge, a Baptist minister settled at Beloit, W[isconsin] 'T[erritory]. She was brought up in [the] Pres[byterian] Church. Mr. $\mathrm{T}$ [rowbridge], it native of Vermont, [was] one of the earliest settlers in [the] neighborhood of Chicago. 
Mr. Trott, in digging a cellar by [the] side of his store in Bellevue, struck upon a skeleton. 'The teeth were in a good state of preservation.

Mr. Rudolp's[?] mother on Brush creek is entirely blind. She lost the use of one eye some thirteen years ago and of the other five years ago, is 63 years old, [and] a native of Germany. His wife is [a] member of Seceder Church, and was in childhood at school with Mr. Vincent (p. 110).

Mr. Vaughn, [is a] native of Virginia, [and] his wife of East Tennessee, [and] neither of them can read, have no Bible.

June 2. I had yesterday in the afternoon a very interesting union meeting of the three Sabbath Schools (the one at Mr. Doan's, this place, and Bloomfield) at Mr. Sam'l Wrights. There were 111 scholars present. They were generally attentive and seemed interested. The meeting [127] was a very encouraging one. There were altogether about 200 persons present. I preached on the 5th commandment. Presents were distributed to the children.

June 4. Visited yesterday afternoon the site of an Indian village or council fire on the south bank of the Maquoketa $3 / 4$ of a mile below the mouth of Mill creck-situated on a high level bank. Saw a number of holes probably used for burying corn, there were indications that fire had been in one of the holes as there were cinders on its sides. Mr. Decatur supposed that the Indians had used these holes for baking, thus making a fire on stones and then baking their meat upon the hot stones as in an oven. We picked up a stone cut very much in the shape of a large axe. There were a number of cedar posts in the ground

placed so as to make a triangle thus $\bullet^{\bullet} \bullet$ in which mayhap some important council was once held. The burnt stones at one side showed us where the fire had been. There are also indications of an Indian town on the other side of the river. How few memorials the savage leaves behind him.

Detroit, Michigan. June 21, 1845. Left Deacon Cotton's on my route hither June 11th. At Galena fell in with Rev. S. [or L?] H. [128] Hayes of Frankfort, Maine with whom I was formerly acquainted at Bangor. He is of amiable disposition, clear and tasteful mind, and warm heart. It was good to meet an old friend in that new world. Also [fell in] with Rev. S. Thurston, Searsport, Me., where he has been settled 20 years, a warm hearted, kind feeling man, an easy affluent writer and speaker, and with Rev. Wm. Atwater[?] of Middlebury, Conn't, a good sober man. Their Company was very delightful and entertaining, besides relieving the tedium of travelling. At Chicago became acquainted with Rev. R. W. Patterson, has a smirk on his face, a man of clear logical mind, decided in his Presbyterian preferences. Had a very pleasant company on the voyage from Chicago to this place. Dr. Lindsley preached one evening, and one evening we had [an] Educational address. Rev. 'T. M. [or W?] Hopkins of Racine, W[isconsin] 
$\mathrm{T}$ [erritory] has many correct views, is opinionated, remarked to me that he thought the Convention in Wisconsin would, as the country grew, resolve themselves into their original distinctive organizations. The subject of establishing a religious paper at Chicago under [the] care of Rev. Mr. Wilkin (formerly of the Watchman of the Valley, and of the Hudson Observor) was discussed. The general fecling is that such a paper is needed and might be sustained.

I am generally pleased with the deliberations [129] of the Convention. Hev. A. T. Hopkins is one of the most promising men, he is aged 40, heard him preach, has an animated style, rapid delivery, he is much interested in and properly awake to the cause of academical Education in the West. Dr. Lindsley of Marietta College is of lovely spirit, a prudent practical mind. Dr. Beecher is full of courage and hope. Prof. Stode is rather dogmatic, a man of wonderful activity and energy. Dr. Berman has got a hobby in his hymn book, "The Church Psalmist" on the merits of which he dilated before the Convention, in very bad taste, as $\mathrm{I}$ thought. $\mathrm{He}$ is a most accomplished Christian minister of dignity and grace in style and manners, of remarkably well balanced mind on all subjects, but that of his hymn book. Mr. Basset and Mr. Backus[?] made some rather injudicious remarks on slavery, and yet I could hardly blame their intemperate expressions on so dreadful an evil. Mr. Blanchard ${ }^{121}$ of Cincinatti is a promising man-he is one of the foremost in the Anti Slavery enterprise, is an earnest enthusiastic speaker. Mr. Hallock, Superintendent of the Sabbath School in [the] Pres[byterian] Ch[urch] of Detroit, [is] an excellent devoted man, has been the superintendent for many years. [I] met with Mrs. Raymond, daughter of Capt. Mash[?] of Norwalk, Conn't and her mother.

Enjoyed in Detroit the hospitality of Mr. King's family. [130] Mrs. $\mathrm{K}$ [ing] [is] an affectionate kind lady. The little daughter Jane [is] an interesting child.

In Buffalo [I] visited in Mr. Hopkin's family. Miss Jane Brush[?] is affianced to Br. Turner. She possesses a cultivated mind, an amiable disposition, excellent judgment, warm heart and unites many excellent qualities in character. She promises to be an inestimable blessing to Br. T[urner] and to our moral and religious strength in Iowa. In Albany [I] called on Miss Stone, [a] cousin to Miss Brush.

$\mathrm{N}[\mathrm{ew}]$ York. [I] arrived home Wednesday morning, July 2. Found all well and desire to be grateful to the Great Preserver of Men.

Nov. 12, 1845. Visited Mr. Smith (his wife an aunt of Calvin Davis) who is living in Mr. Fletcher's[?] house. Mr. and Mrs. S[mith] were

121 Rev. Jonathan Blanclard (1811-1892) was graduated from Middlebury College in 1832. taught at Plattsburg Academy, studied at Andover and Lane Theological Seminary in Cincinnat. In 1838 he was ordained pastor of the Sixth Presbyterian Church there, and in 1845 he was elected president of $K$ nox College. at Galesburg, llinois, and in 1800 became presirent of wheaton College. Whenton. Illinois. He was a strong temperance advocate and a violent abolitionist. Vid. Diclionary of American Biography. 
members of a Congregational Church in Wolcott, Vermont in a neighborhood burnt over with Millerism.

Dec. 3. Visited this week Mrs. Macloy, Mr. Reynolds, Mrs. Marshall, Mr. Haines, Mr. Ninnes[?] Mr. Estebrook.

Nov. 1, 1845. The subscription for me at Andrew amounts to $\$ 35$.at Makoqueta to $\$ 54.50$. The two Churches ask for me from the A. H. M. S. [the sum of] $\$ 310.50$. The applicaction [was] forwarded to $\mathrm{Br}$. Reed [on] Dec. 29th.

Jan. 1, 1846. I preached 146 sermons the last year, 10 of them funeral sermons.

\section{EMIGRATION}

Emigrants are flocking to the West by scores, by hundreds and by thousands. We understand that boats from the Ohio River come into Saint Louis literally crowded with families seeking new homes on the western prairies. From Saint Louis many go up the Missouri River to settle in the Platte country, a few up the Illinois, and after dropping off at the various inviting places on the upper Mississippi, many reach our place and locate in town, or go back into the country. We are glad to see them coming. An industrious population is all that is required to make Iowa one of the richest countries in the world. -Bloomington (Muscatine) Herald, April 28, 1843. (In the Newspaper Division of the Ilistorical, Memorial and Art Department of Iowa.) 
Copyright of Annals of Iowa is the property of State of Iowa, by \& through the State Historical Society of Iowa and its content may not be copied or emailed to multiple sites or posted to a listserv without the copyright holder's express written permission. However, users may print, download, or email articles for individual use. 